\title{
THE LEVELS OF CRITICAL THINKING TENDENCIES IN ARCHITECTURAL EDUCATION
}

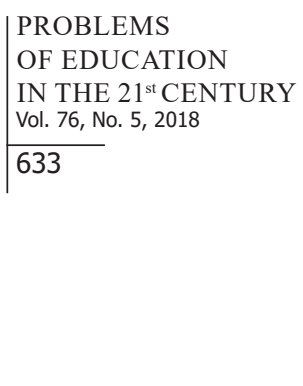

PROBLEMS

OF EDUCATION

Vol. 76, No. 5, 2018

633

\author{
Hare Kiliçaslan \\ Karadeniz Technical University, Turkey \\ E-mail: hkkilicaslan@gmail.com
}

\begin{abstract}
Students who receive architectural education are expected to be individuals who can think critically. For this reason, it becomes a necessity to cultivate creative individuals who are curious, inquiring and multifaceted thinkers. The aim of this research was to determine the levels of tendency for critical thinking of first-year and fourth-year architecture students. The research sample consisted of 88 (54 females, 34 males) first-year and 83 (47 females, 36 males) fourth-year students who are studying at Karadeniz Technical University, Faculty of Architecture, Department of Architecture. The "California Critical Thinking Disposition Inventory (CCTDI)" was used as data collection tool in the research. In addition, information about the demographic characteristics of students were collected through the Personal Information Form. Findings of the research showed that there was no statistically significant difference between the GPAs and critical thinking tendency levels of the first-year and fourth-year students. It can be argued that all students need some guidance to attach importance on critical thinking starting from the first year of the program.
\end{abstract}

Keywords: academic achievement, architectural students, critical thinking, critical thinking tendency.

\section{Introduction}

Changes in the education system render liberating learning environments that bring critical thinking into the forefront pivotal. University level education aims the versatile development of individuals as well as gaining professional knowledge. Educational processes that will ensure the comprehension of environmental, social and professional realities and production of critical knowledge should be established. Therefore, by thinking together with changing technologies and concepts, education needs to be realized with the understanding of searching for solutions together instead of a one-way teacher-student relation.

The critical pedagogical approach defends a dialogist education process where teachers and students learn and teach simultaneously and search for knowledge together, rather than classical education methods. Students' departing from being the objects of the education process and becoming subjects of it during the dialogist education process transforms learning into a practice of liberation (Uysal \& Y1ldız, 2014).

Conducting the education process with a tutor-centered one-way flow of information renders the learning environment ineffective. Learning experiences should improve students' thinking skills and lead them to think critically and creatively (Demirel, 2009; Güleç, 1997). Thinking is a conscious mental process set forth to solve a problem, make a decision, or develop understanding. There are three basic categories of thinking as reflective, creative and critical (Ruggiero, 2012).

Critical thinking does not refer to the same concept as thinking. One of the two requirements for critical thinking is the reflectivity of thought. The other one is that this reflective 
Hare KILIÇASLAN. The levels of critical thinking tendencies in architectural education

\section{PROBLEMS \\ OF EDUCATION \\ IN THE $21^{\text {st }}$ CENTURY Vol. 76, No. 5, 2018 \\ 634}

thinking meets high standards (Nosich, 2012). Glaser (1941) defines critical thinking as the skills towards approaching to the problems and issues that arise depending on experiences in a thoughtful way, towards the knowledge of logical inquiry and reasoning methods and the implementation of these methods. Critical thinking, according to Schafersman (1991), refers to thinking right in search of relevant and reliable information about the world.

Critical thinking is a process involving interpreting, analyzing, evaluating, and deducing with a purpose, and the judgment attained is based on evidentiary, conceptual, methodological, critical or contextual evaluations (Facione, 2013). Critical thinking is defined as reflective thinking that focuses on what to believe and what to do. It involves the verification of hypotheses and the logical decision-making process (Ennis, 1985; 1996). Similarly, Lipman (2003) defines critical thinking as skillful and liable thinking that leads to a well judgment. Because, it cares about the context it is located, it is established on criteria and has a self-corrective structure.

Nosich (2012) posits that critical thinking has three parts. These can be summarized as follows:

1. It involves asking questions. Questions that need to be answered and aims at the core of the issue need to be asked.

2. It involves trying to solve the questions asked by apprehending their logic. The effects should be well analyzed by extracting the results based on causes and attaching necessary weight to all the relevant factors.

3. It involves the logic's believing in the effects. When critical thinning is applied on a subject matter, the effects are internalized, and the answers are reached. This final step is not always easy to implement. This is an indication that the event is not cogitated as critical and that there are other questions to be asked.

Based on these three parts mentioned, it can be argued that for critical thinking, one should think on questions, attain a logical conclusion, believe in it and behave in compliance with this belief.

Halpern (1999) emphasizes that when thought critically, the outcomes of the thought processes about how good a decision is or how well a problem is solved are contemplated.

The mentioned theoretical information refers to the place and importance of critical thinking in architectural education. Because, thinking critically on a certain field entails thinking with the terms in that field. Thinking critically in architecture is to think architecturally. According to Yücel and Aydınlı (2015), architecture environment involves a multiple information environment from past to present. Many physical and social active factors and qualities related to various periods of the past make it necessary for the architect to understand and interpret the conditions that he/she is in. This situation is shaped hinging upon the knowledge and skills of understanding and interpretation, being able to think critically and relationally and being able to react positively or negatively.

It is aimed to gain the students with competences such as thinking originally, creatively and critically with architectural education. When the concepts related to the subjects are understood by the students, when the information is related to other concepts, when questions about the subject can be asked and when the acquired information can be adapted to the new situations, it can be argued that one has the content of a certain course. Therefore, in order to ask questions related to the field and thinking critically, the architectural concepts need to be internalized. From this perspective, it is obvious that students of architecture education should be directed to ask questions using the architectural concepts they encounter in their daily lives and to think about these questions.

Since architecture is a discipline that constantly renews itself, architectural education is also expected to adapt to these changes. In communication-based critical learning environments, there is a guidance for obtaining information by thinking and using them in a conscious and objective manner. From this perspective, it seems valuable to examine the impact of current architectural education on critical thinking tendencies of the students. A method was followed to define the levels of students' critical thinking tendencies, to explore whether theoretical dimension of critical thinking and practical results meet or not. 
When the literature is examined, it has been found that many studies have been made on critical thinking in different learning areas; however, it was seen that the level of critical thinking tendency of the students in architectural education was not discussed in any research. In this context, the research aimed to reveal the levels of tendency for critical thinking of the students studying architecture. For this purpose, answers to the following questions were sought:

1. On what level are the critical thinking tendencies of students?

2. Is there a significant difference between the mean critical thinking tendency scores of the first-year and fourth-year students?

3. Is there a significant difference between the mean critical thinking tendency scores and academic achievements of students?

4. Do students' mean critical thinking tendency scores significantly differ according to their:

a) Gender,

b) Settlement places they have spent most of their lives,

c) Parents' level of education.

\section{Methodology of Research}

\section{The Research Model}

The research was conducted at Karadeniz Technical University Faculty of Architecture Department of Architecture in April to June 2018. The aim of this research is to determine the levels of tendency for critical thinking of first and fourth year students who are studying architecture within the framework of grade point averages, and to examine them in terms of gender, class level, settlement place and parents' educational level.

In this research, the relational screening model (Karasar, 2016) which is among the general screening models was used. Screening models are appropriate approaches for researches that aim to describe a past or currently existing situation in the way it exists. In general, screening models are screening applications applied on the entire population or a group of sample or sampling in order to have a general judgment of a population that consists of a large number of elements. The relational screening models that take place in this group are research models aiming to determine the existence of co-variance or the level of variance between two or more variables (Büyüköztürk et al., 2018; Karasar, 2016).

\section{Participants}

A total of 171 students, 88 (54 females, 34 males) first-year and 83 (47 females, 36 males) fourth-year students, who are studying at Karadeniz Technical University Faculty of Architecture Department of Architecture participated in the research. Distribution of the participants' demographic characteristics are presented in Table 1.

PROBLEMS

OF EDUCATION

IN THE $21^{\text {st }}$ CENTURY

Vol. 76, No. 5, 2018 
PROBLEMS

OF EDUCATION IN THE $21^{\text {st }}$ CENTURY Vol. 76, No. 5, 2018

Table 1. Demographic characteristics of the participants of the research.

\begin{tabular}{lll}
\hline Gender & Number & Percentage \\
\hline Female & 101 & 59.1 \\
\hline Male & 70 & 40.9 \\
\hline Total & 171 & 100 \\
\hline Year & & \\
\hline First-year & 88 & 51.5 \\
\hline Fourth-year & 83 & 48.5 \\
\hline Total & 171 & 100 \\
\hline Academic GPA & & \\
\hline $1.50-2.00$ & 5 & 2.9 \\
\hline $2.01-2.50$ & 36 & 21.1 \\
\hline $2.51-3.00$ & 63 & 36.8 \\
\hline $3.01-3.50$ & 59 & 34.5 \\
\hline $3.51-4.00$ & 8 & 4.7 \\
\hline Total & 171 & 100 \\
\hline Mother's level of educational & & \\
\hline Illiterate & 3 & 1.8 \\
\hline Literate & 5 & 2.9 \\
\hline Primary-secondary school & 86 & 50.3 \\
\hline High school & 51 & 29.8 \\
\hline University & 23 & 13.5 \\
\hline Graduate degree & 3 & 1.8 \\
\hline Total & 171 & 100 \\
\hline Father's level of educational & & \\
\hline Illiterate & 1 & .6 \\
\hline Literate & 1 & .6 \\
\hline Primary-secondary school & 48 & 28.1 \\
\hline High school & 55 & 32.2 \\
\hline University & 59 & 34.5 \\
\hline Graduate degree & 7 & 4.1 \\
\hline Total & 171 & 100 \\
\hline & & \\
\hline & 59 & \\
\hline
\end{tabular}

When the distribution of the demographical characteristics in Table 1 are examined, it is determined that $59.1 \%$ of the students participated in the research are female, $40.9 \%$ are male, $51.5 \%$ are in the first-year and $48.5 \%$ are in the fourth-year. $2.9 \%$ of students have GPAs in the range of $1.50-2.00,21.1 \%$ in the range of $2.01-2.50,36.8 \%$ in the range of $2.51-3.00,34.5 \%$ in the range of 3.01-3.50 and 4.7\% in the range of 3.51-4.00. A Mann Whitney $U$ test (Table 2) was run to determine whether there is a significant difference between the GPAs of first-year and fourth-year students.

Table 2. Results of the difference between students' GPAs according to class level.

\begin{tabular}{lllll}
\hline Academic GPA & $\boldsymbol{N}$ & Mean rank & $\boldsymbol{U}$ & $\boldsymbol{p}$ \\
\hline First-year & 88 & 76.52 & 2818.00 & $.007^{*}$ \\
\hline Fourth-year & 83 & 96.05 & &
\end{tabular}

According to the results of the Mann Whitney U test, it was found that the difference between students' academic grade point averages was statistically significant at $95 \%$ significance level ( $U=2818.00, p=.007, p<.05$ ). As shown in Table 2, fourth-year students' GPAs (Mean rank=96.05) are higher in comparison to the first-year students (Mean rank=76.52). 


\section{Data Collection Tools}

The Personal Information Form

This is the form developed in the research in order to collect data on students' demographical characteristics such as gender, settlement places and parents' level of education. The data on students' academic grade point averages are obtained from the Department of Architecture of the Karadeniz Technical University, within ethical procedures.

\section{The Critical Thinking Scale}

In the research, the California Critical Thinking Disposition Inventory (CCTDI)", developed by Facione et al. (1998), was used to determine students' level of critical thinking tendency. CCTDI is used not to measure a skill but to assess one's tendency to think critically or, in a more comprehensive expression, the level of thinking critically. There are 75 items in this scale which has 7 institutionally identified and tested sub-dimensions. As a result of the validity and reliability studies conducted on the Turkish version of the scale (CCTDI-T) which was adapted by Kökdemir (2003), the scale consists of a total of 6 subscales and 51 items. The responses given to the 6-point Likert type scale were summed up and the raw scores for each subscale were calculated. The raw scores were converted into a standard score with a minimum value of 6 and maximum value of 60 by diving the scores by the number of items and multiplying by 10 . The lowest and highest possible values are fixed for all subscales. Therefore, when CCTDI-T is evaluated as a whole, those whose scores are lower than $240(40 \times 6)$ are considered to have lower general critical thinking tendency while those who have higher than $300(50 \times 6)$ are considered to have higher tendency. The internal consistency (Alpha) coefficient of the scale was found as .88 by Kökdemir (2003). The scale explains $36.13 \%$ of the total variance. The Cronbach Alpha value of the scale calculated in this research was .75. Considering the fact that the general acceptance threshold for internal consistency is .70, it is seen that the data obtained from the survey are at an acceptable level.

Subscales of the CCTDI-T scale are as follows (Kökdemir, 2003):

The Analyticity Subscale: The analyticity subscale, which indicates the tendency to be careful against potentially problematic situations and to use reasoning and objective evidence even in difficult problems, consists of a total of 10 items. The eigenvalue of the Analyticity subscale was found to be 8.63 , the variance it explains was $15.40 \%$ and its internal consistency (Alpha) coefficient was .75.

The Open-Mindedness Subscale: Open mindedness expresses the tolerance of the person against different approaches and his/her sensitivity to self mistakes. The basic logic in open-mindedness is that when an individual makes a decision, he or she not only heeds his own thoughts, but also the views and thoughts of others. The eigenvalue of the Open-mindedness subscale which consists of a total of 12 items was found to be 4.02, the variance it explains was $7.17 \%$ and its internal consistency (Alpha) coefficient was .75.

The Inquisitiveness Subscale: Inquisitiveness or intellectual curiosity reflects the person's tendency to acquire knowledge and learn new things without any expectation of having a gain or interest. The inquisitiveness subscale is composed of 9 items in total. The eigenvalue of the Inquisitiveness subscale was found to be 2.62 , the variance it explains was $4.68 \%$ and its internal consistency (Alpha) coefficient was .78.

The Self-Confidence Subscale: Self-confidence reflects the confidence one bears in the self-reasoning processes. The eigenvalue of the Self-confidence subscale that consists of a total of 7 items was found to be 1.90 , the variance it explains was $3.40 \%$ and its internal consistency (Alpha) coefficient was .77.

The Truth-Seeking Subscale: This subscale measures the tendency to consider alternatives or different thoughts. Having a high score in this subscale shows that the person's tendency 
Hare KILIÇASLAN. The levels of critical thinking tendencies in architectural education

PROBLEMS

OF EDUCATION

IN THE $22^{\text {st }}$ CENTURY Vol. 76, No. 5, 2018

638

towards truth seeking, skills for asking questions, and probability of behaving objectively even in situations where facts against his/her thoughts are in question is high. A total of 7 items are used to measure the Truth-seeking dimension. The eigenvalue of the truth-seeking subscale was found to be 1.56 , the variance it explains was $2.79 \%$ and its internal consistency (Alpha) coefficient was .61.

The Systematicity Subscale: Systematicity is an organized, planned and careful inclination for searching. It refers to a tendency to use a decision-making strategy that is knowledge-based and follows a specific procedure rather than a chaotic reasoning behavior. High scores indicate tendency to more systematic, careful and organized thinking. A total of 6 items are used to measure the Systematicity dimension. The eigenvalue of the Systematicity subscale was found to be 1.50 , the variance it explains was $2.68 \%$ and its internal consistency (Alpha) coefficient was .63.

\section{Data Analysis}

Compliance of the obtained data with the normal distribution was determined by the Kolmogorov-Smirnov test. In order to detect statistically significant differences, Mann Whitney $U$ test and Kruskal Wallis tests were used. The significance level of the data analysis was assumed $p=.05$.

Tests of normality were run for the data obtained in the research. The mean score, minimum and maximum score range, skewness and kurtosis coefficients were calculated within the scope of this analysis. Since the number of participants was over 50, compliance of the obtained data with the normal distribution was determined by the Kolmogorov-Smirnov test. According to the tests performed, the results of the normality tests for the scores of the measurement sets are presented below (Table 3).

Table 3. Results of normality tests for distribution of data.

\begin{tabular}{|c|c|c|c|c|c|c|}
\hline & \multicolumn{3}{|c|}{ Kolmogorov-Smirnov (a) } & \multirow[t]{2}{*}{ Median } & \multirow[t]{2}{*}{ Skewness } & \multirow[t]{2}{*}{ Kurtosis } \\
\hline & Statistic & $\mathrm{df}$ & $p$ & & & \\
\hline Analyticity & .101 & 171 & .0001 & 48.00 & -.665 & 1.555 \\
\hline Open-mindedness & .121 & 171 & .0001 & 30.00 & .673 & .497 \\
\hline Inquisitiveness & .064 & 171 & .0870 & 42.00 & -.183 & -.237 \\
\hline Self-confidence & .097 & 171 & .0001 & 28.00 & -.551 & .215 \\
\hline Truth-seeking & .098 & 171 & .0001 & 21.00 & .256 & -.370 \\
\hline Systematicity & .076 & 171 & .0180 & 20.00 & .152 & -.332 \\
\hline
\end{tabular}

Kolmogorov-Smirnov (a) analysis revealed that distribution of data related to the Inquisitiveness and Systematicity subscales is normal $(p>.05)$ However, distribution of data related to the Analyticity, Open-mindedness, Self-confidence and Truth-seeking subscales is not normal $(p<.05)$. When the other assumptions of normality, which are the proximity of the mean and median to each other and the necessity that the values of skewness and kurtosis to be between -2.5 and +2.5 , are examined, it is determined that these values comply with the normal distribution according to the variables. In the central limit theorem, it is posited that a sample size more than 30 makes the distribution close to normal. Since the sample size was 171 in this research, it is concluded that even though the distribution is not normal, it is not far away from the normal distribution given the central limit theorem. In the light of this information, it is determined that the data is not far away from normal distribution (Table 3).

Statistical analysis was performed using the Statistical Package for the Social Sciences (SPSS 18.0). Data analysis was valid at 95\% confidence level and the significance level was taken as .05. 


\section{Results of Research}

Levels of Critical Thinking Tendency

Results related to students' levels of critical thinking tendency are summarized in Table 4. When the descriptive statistics on the California Critical Thinking Disposition Inventory is examined, "Analyticity" (Mean rank $=47.89$, Mean rank=47.68) was found to be the subscale with the highest level while "Systematicity" (Mean rank=20.51, Mean rank=19.95) was found to be the subscale with the lowest level in both groups (Table 4).

Table 4. Descriptive statistics on the California Critical Thinking Disposition Inventory.

\begin{tabular}{lllllll}
\hline \multirow{2}{*}{ Subscales } & \multicolumn{2}{l}{ First-year } & \multicolumn{5}{l}{ Fourth-year } \\
\cline { 2 - 7 } & $\mathbf{N}$ & $\begin{array}{l}\text { Mean } \\
\text { rank }\end{array}$ & $\mathbf{S D}$ & $\mathbf{N}$ & Mean rank & SD \\
\hline Analyticity & 88 & 47.89 & 5.09 & 83 & 47.68 & 5.29 \\
\hline Open-mindedness & 88 & 30.09 & 6.97 & 83 & 31.73 & 7.75 \\
\hline Inquisitiveness & 88 & 42.39 & 5.56 & 83 & 41.90 & 4.84 \\
\hline Self-confidence & 88 & 27.07 & 5.34 & 83 & 28.25 & 4.44 \\
\hline Truth-seeking & 88 & 20.67 & 5.14 & 83 & 22.15 & 5.66 \\
\hline Systematicity & 88 & 20.51 & 3.78 & 83 & 19.95 & 3.30 \\
\hline
\end{tabular}

Critical Thinking Tendencies According to Class Levels

A Mann Whitney $U$ test was run to determine whether there is any significant difference in terms of the California Critical Thinking Disposition Inventory scores between first-year and fourth-year students (Table 5).

Table 5. Results of students' scores of subscales according to class levels.

\begin{tabular}{|c|c|c|c|c|c|}
\hline Subscales & Class level & $N$ & Mean rank & $U$ & $p$ \\
\hline Analyticity & $\begin{array}{l}\text { First-year } \\
\text { Fourth-year }\end{array}$ & $\begin{array}{l}88 \\
83\end{array}$ & $\begin{array}{l}86.53 \\
85.44\end{array}$ & 3605.50 & .880 \\
\hline Open-mindedness & $\begin{array}{l}\text { First-year } \\
\text { Fourth-year }\end{array}$ & $\begin{array}{l}80 \\
83\end{array}$ & \begin{tabular}{|l|}
81.82 \\
90.43
\end{tabular} & 3284.50 & .255 \\
\hline Inquisitiveness & $\begin{array}{l}\text { First-year } \\
\text { Fourth-year }\end{array}$ & $\begin{array}{l}88 \\
83\end{array}$ & $\begin{array}{l}89.11 \\
82.70\end{array}$ & 3378.00 & .396 \\
\hline Self-confidence & $\begin{array}{l}\text { First-year } \\
\text { Fourth-year }\end{array}$ & $\begin{array}{l}88 \\
83\end{array}$ & $\begin{array}{l}82.09 \\
90.14\end{array}$ & 3308.00 & .287 \\
\hline Truth-seeking & $\begin{array}{l}\text { First-year } \\
\text { Fourth-year }\end{array}$ & $\begin{array}{l}88 \\
83\end{array}$ & $\begin{array}{l}80.25 \\
92.10\end{array}$ & 3146.00 & .117 \\
\hline Systematicity & $\begin{array}{l}\text { First-year } \\
\text { Fourth-year }\end{array}$ & $\begin{array}{l}88 \\
83\end{array}$ & $\begin{array}{l}88.84 \\
82.99\end{array}$ & 3402.00 & .438 \\
\hline
\end{tabular}

According to the results of the Mann Whitney U test, no statistically significant difference was found between students' critical thinking tendencies according to their class levels $(p>.05)$. Hence, it can be argued that students' level of critical thinking does not differ according to the class level they are studying in. 
Hare KILIÇASLAN. The levels of critical thinking tendencies in architectural education

PROBLEMS

OF EDUCATION

IN THE $21^{\text {st }}$ CENTURY

Vol. 76, No. 5, 2018

640

Critical Thinking Tendencies According to GPAs

A Kruskal Wallis $\mathrm{H}$ test was run to determine whether there is a significant difference between students' critical thinking tendencies according to their GPAs (Table 6).

Table 6. Results of differences between students' scores of subscales according to their GPAs.

\begin{tabular}{|c|c|c|c|c|c|c|}
\hline Subscales & Academic GPA & $N$ & Mean rank & $\chi^{2}$ & $S D$ & $p$ \\
\hline \multirow{5}{*}{ Analyticity } & $1.50-2.00$ & 5 & 84.50 & \multirow{5}{*}{8.686} & \multirow{5}{*}{4} & \multirow{5}{*}{$.06 \varsigma$} \\
\hline & $2.01-2.50$ & 36 & 73.93 & & & \\
\hline & $2.51-3.00$ & 63 & 80.54 & & & \\
\hline & $3.01-3.50$ & 59 & 94.61 & & & \\
\hline & $3.51-4.00$ & 8 & 120.75 & & & \\
\hline \multirow{5}{*}{ Open-mindedness } & $1.50-2.00$ & 5 & 70.50 & \multirow{5}{*}{5.381} & \multirow{5}{*}{4} & \multirow{5}{*}{.250} \\
\hline & $2.01-2.50$ & 36 & 88.42 & & & \\
\hline & $2.51-3.00$ & 63 & 90.87 & & & \\
\hline & $3.01-3.50$ & 59 & 85.48 & & & \\
\hline & $3.51-4.00$ & 8 & 50.25 & & & \\
\hline \multirow{5}{*}{ Inquisitiveness } & $1.50-2.00$ & 5 & 81.60 & \multirow{5}{*}{9.440} & \multirow{5}{*}{4} & \multirow{5}{*}{.051} \\
\hline & $2.01-2.50$ & 36 & 77.71 & & & \\
\hline & $2.51-3.00$ & 63 & 81.10 & & & \\
\hline & $3.01-3.50$ & 59 & 90.25 & & & \\
\hline & $3.51-4.00$ & 8 & 133.31 & & & \\
\hline \multirow{5}{*}{ Self-confidence } & $1.50-2.00$ & 5 & 83.30 & \multirow{5}{*}{8.239} & \multirow{5}{*}{4} & \multirow{5}{*}{.083} \\
\hline & $2.01-2.50$ & 36 & 82.90 & & & \\
\hline & $2.51-3.00$ & 63 & 79.43 & & & \\
\hline & $3.01-3.50$ & 59 & 88.98 & & & \\
\hline & $3.51-4.00$ & 8 & 131.38 & & & \\
\hline \multirow{5}{*}{ Truth-seeking } & $1.50-2.00$ & 5 & 76.10 & \multirow{5}{*}{5.664} & \multirow{5}{*}{4} & \multirow{5}{*}{.226} \\
\hline & $2.01-2.50$ & 36 & 94.17 & & & \\
\hline & $2.51-3.00$ & 63 & 92.32 & & & \\
\hline & $3.01-3.50$ & 59 & 78.55 & & & \\
\hline & $3.51-4.00$ & 8 & 60.63 & & & \\
\hline \multirow{5}{*}{ Systematicity } & $1.50-2.00$ & 5 & 62.40 & \multirow{5}{*}{6.102} & \multirow{5}{*}{4} & \multirow{5}{*}{.192} \\
\hline & $2.01-2.50$ & 36 & 102.10 & & & \\
\hline & $2.51-3.00$ & 63 & 81.11 & & & \\
\hline & $3.01-3.50$ & 59 & 82.38 & & & \\
\hline & $3.51-4.00$ & 8 & 93.50 & & & \\
\hline
\end{tabular}

According to the Kruskal Wallis $\mathrm{H}$ test, no statistically significant difference between students' critical thinking tendencies and their academic GPAs was found $(p>.05)$. When the data given in the table 6 is examined, it is seen that students with 3.51-4.00 GPAs have the highest mean score (Mean rank=120.75) while those with 2.01-2.50 GPAs have the lowest (Mean rank=73.93) in the "Analyticity" subscale. In the "Open-mindedness" subscale, students with 2.51-3.00 GPAs have the highest mean score (Mean rank=90.87) while those with 3.514.00 GPAs have the lowest (Mean rank=50.25). In the "Inquisitiveness" subscale, students with 3.51-4.00 GPAs have the highest mean score (Mean rank=133.31) while those with 2.01-2.50 GPAs have the lowest (Mean rank=77.71). In the "Self-Confidence" subscale, students with 3.51-4.00 GPAs have the highest mean score (Mean rank=131.38) while those with 2.51-3.00 GPAs have the lowest (Mean rank=79.43). In the "Truth-Seeking" subscale, students with 2.012.50 GPAs have the highest mean score (Mean rank=94.17) while those with 3.51-4.00 GPAs have the lowest (Mean rank=60.63). In the "Systematicity" subscale, students with 2.01-2.50 GPAs have the highest mean score (Mean rank=102.10) while those with 1.50-2.00 GPAs have the lowest (Mean rank=62.40). 
A Mann Whitney $U$ test was run to determine whether there is a significant difference in terms of students' California Critical Thinking Disposition Inventory mean scores according to gender (Table 7).

Table 7. Results of differences between students' scores of subscales according to their genders.

\begin{tabular}{|c|c|c|c|c|c|}
\hline Subscales & Gender & $N$ & Mean rank & $U$ & $p$ \\
\hline \multirow{2}{*}{ Analyticity } & Female & 101 & 92.60 & \multirow{2}{*}{2868.00} & \multirow{2}{*}{$.036^{*}$} \\
\hline & Male & 70 & 76.47 & & \\
\hline \multirow{2}{*}{ Open-mindedness } & Female & 101 & 76.49 & \multirow{2}{*}{2574.50} & \multirow{2}{*}{$.003^{*}$} \\
\hline & Male & 70 & 99.72 & & \\
\hline \multirow{2}{*}{ Inquisitiveness } & Female & 101 & 88.58 & \multirow{2}{*}{3274.50} & \multirow{2}{*}{.412} \\
\hline & Male & 70 & 82.28 & & \\
\hline \multirow{2}{*}{ Self-confidence } & Female & 101 & 91.97 & \multirow{2}{*}{2932.00} & \multirow{2}{*}{.058} \\
\hline & Male & 70 & 77.39 & & \\
\hline \multirow{2}{*}{ Truth-seeking } & Female & 101 & 81.36 & \multirow{2}{*}{3066.50} & \multirow{2}{*}{$.014^{*}$} \\
\hline & Male & 70 & 92.69 & & \\
\hline \multirow{2}{*}{ Systematicity } & Female & 101 & 93.98 & \multirow{2}{*}{2729.00} & \multirow{2}{*}{$.011^{*}$} \\
\hline & Male & 70 & 74,49 & & \\
\hline
\end{tabular}

Results of the Mann Whitney U test shows that, the difference between students' "Analyticity" levels according to their genders is statistically significant at $95 \%$ confidence level ( $U=2868.00, p=.036, p<.05$ ) It is seen that females have higher (Mean rank=92.60) "Analyticity" level than males (Mean rank=76.47) The difference between students" "Open-mindedness" levels according to their genders is found to be statistically significant at $95 \%$ confidence level $(U=2575.50, p=.003, p<.05$ ). Males (Mean rank=99.72) have higher "Open-mindedness" levels than females (Mean rank=76.49). The difference between students' "Inquisitiveness" levels according to their genders is found to be statistically insignificant ( $U=3274.50, p=.412, p>.05$ ). The difference between students' "Self-confidence" levels according to their genders is found to be statistically insignificant ( $U=2932.00, p=.058, p>.05$ ). The difference between students' "Truth-seeking" levels according to their genders is found to be statistically significant at $95 \%$ confidence level $(U=3066.50, p=.014, p<.05)$. Males were found to have higher (Mean rank=92.69) "Truth-seeking" levels than females (Mean rank=81.36). The difference between "Systematicity" levels according to their genders is found to be statistically significant at $95 \%$ confidence level $(U=2729.00, p=.011, p<.05)$. It is seen that females have higher (Mean rank=93.98) "Systematicity" levels than males (Mean rank=74.49).

A Kruskal Wallis $H$ test was run to determine whether there is any significant difference between students' critical thinking tendencies according to the settlement places they spend most of their times (Table 8). 
Hare KILIÇASLAN. The levels of critical thinking tendencies in architectural education

PROBLEMS

OF EDUCATION

IN THE $21^{\text {st }}$ CENTURY

Vol. 76, No. 5, 2018

642

Table 8. Results of differences between students' scores of subscales according to their settlement places.

\begin{tabular}{|c|c|c|c|c|c|c|}
\hline Subscales & Settlement places & $N$ & Mean rank & $\chi^{2}$ & $S D$ & $p$ \\
\hline \multirow{4}{*}{ Analyticity } & Village-town & 14 & 96.61 & \multirow{4}{*}{1.560} & \multirow{4}{*}{3} & \multirow{4}{*}{.668} \\
\hline & District & 41 & 79.34 & & & \\
\hline & Province & 59 & 85.56 & & & \\
\hline & Metropolitan city & 57 & 88.64 & & & \\
\hline \multirow{4}{*}{ Open-mindedness } & Village-town & 14 & 110.50 & \multirow{4}{*}{3.925} & \multirow{4}{*}{3} & \multirow{4}{*}{.270} \\
\hline & District & 41 & 82.35 & & & \\
\hline & Province & 59 & 85.97 & & & \\
\hline & Metropolitan city & 57 & 82.64 & & & \\
\hline \multirow{4}{*}{ Inquisitiveness } & Village-town & 14 & 100.86 & \multirow{4}{*}{4.433} & \multirow{4}{*}{3} & \multirow{4}{*}{.218} \\
\hline & District & 41 & 95.44 & & & \\
\hline & Province & 59 & 77.94 & & & \\
\hline & Metropolitan city & 57 & 83.90 & & & \\
\hline \multirow{4}{*}{ Self-confidence } & Village-town & 14 & 93.96 & \multirow{4}{*}{1.314} & \multirow{4}{*}{3} & \multirow{4}{*}{.726} \\
\hline & District & 41 & 82.99 & & & \\
\hline & Province & 59 & 90.13 & & & \\
\hline & Metropolitan city & 57 & 81.94 & & & \\
\hline \multirow{4}{*}{ Truth-seeking } & Village-town & 14 & 91.39 & \multirow{4}{*}{2.363} & \multirow{4}{*}{3} & \multirow{4}{*}{.501} \\
\hline & District & 41 & 91.49 & & & \\
\hline & Province & 59 & 78.13 & & & \\
\hline & Metropolitan city & 57 & 88.88 & & & \\
\hline \multirow{4}{*}{ Systematicity } & Village-town & 14 & 82.86 & \multirow{4}{*}{2.016} & \multirow{4}{*}{3} & \multirow{4}{*}{.569} \\
\hline & District & 41 & 91.39 & & & \\
\hline & Province & 59 & 89.72 & & & \\
\hline & Metropolitan city & 57 & 79.04 & & & \\
\hline
\end{tabular}

According to the Kruskal Wallis $\mathrm{H}$ test, no statistically significant difference was found between students' critical thinking tendencies according to their settlement units $(p>.05)$. When Table 8 is examined, it is seen that in the "Analyticity" subscale, the highest critical thinking tendency mean score belongs to students who spent most of their lives in "Villages-towns" (Mean rank=96.61) while the lowest mean score belongs to those who live in "Districts" (Mean rank=79.34). In the "Open-mindedness" subscale, the highest critical thinking tendency mean score belongs to students who spent most of their lives in "Villages-towns" (Mean rank=110.50) while the lowest mean score belongs to those who live in "Districts" (Mean rank=82.35). In the "Inquisitiveness" subscale, the highest critical thinking tendency mean score belongs to students who spent most of their lives in "Villages-towns" (Mean rank=100.86) while the lowest mean score belongs to those who live in "Provinces" (Mean rank=77.94). In the "Self-confidence" subscale, the highest critical thinking tendency mean score belongs to students who spent most of their lives in "Villages-towns" (Mean rank=93.96) while the lowest mean score belongs to those who live in "Metropolitan cities" (Mean rank=81.94). In the "Truth-seeking" subscale, the highest critical thinking tendency mean score belongs to students who spent most of their lives in "Districts" (Mean rank=91.49) while the lowest mean score belongs to those who live in "Provinces" (Mean rank=78.13). In the "Systematicity" subscale, the highest critical thinking tendency mean score belongs to students who spent most of their lives in "Districts" (Mean rank=91.39) while the lowest mean score belongs to those who live in "Metropolitan cities" (Mean rank=79.04).

A Kruskal Wallis $\mathrm{H}$ test was run to determine whether there is any significant difference between students' critical thinking tendencies and their mothers' level of education (Table 9). 
Table 9. Results of differences between students' scores of subscales according to their mothers' level of education.

\begin{tabular}{|c|c|c|c|c|c|c|}
\hline Subscales & $\begin{array}{l}\text { Mothers' level of } \\
\text { education }\end{array}$ & $N$ & Mean rank & $\chi^{2}$ & $S D$ & $p$ \\
\hline \multirow{5}{*}{ Analyticity } & $\begin{array}{l}\text { Illiterate } \\
\text { Literate }\end{array}$ & $\begin{array}{l}3 \\
5\end{array}$ & $\begin{array}{l}111.33 \\
93.40\end{array}$ & \multirow{5}{*}{2.903} & \multirow{5}{*}{5} & \multirow{5}{*}{.71} \\
\hline & $\begin{array}{l}\text { Primary-secondary } \\
\text { school }\end{array}$ & 86 & 88.41 & & & \\
\hline & High school & 51 & 78.29 & & & \\
\hline & University & 23 & 86.41 & & & \\
\hline & Graduate degree & 3 & 107.17 & & & \\
\hline \multirow{6}{*}{ Open-mindedness } & |lliterate & 3 & 92.67 & \multirow{6}{*}{8.967} & \multirow{6}{*}{5} & \multirow{6}{*}{.110} \\
\hline & Literate & 5 & 119.10 & & & \\
\hline & $\begin{array}{l}\text { Primary-secondary } \\
\text { school }\end{array}$ & 86 & 85.87 & & & \\
\hline & High school & 51 & 80.40 & & & \\
\hline & University & 23 & 98.72 & & & \\
\hline & Graduate degree & 3 & 25.50 & & & \\
\hline \multirow{5}{*}{ Inquisitiveness } & $\begin{array}{l}\text { Illiterate } \\
\text { Literate }\end{array}$ & $\begin{array}{l}3 \\
5\end{array}$ & $\begin{array}{l}90.67 \\
125.70\end{array}$ & \multirow{5}{*}{5.508} & \multirow{5}{*}{5} & \multirow{5}{*}{.357} \\
\hline & $\begin{array}{l}\text { Primary-secondary } \\
\text { school }\end{array}$ & 86 & 85.19 & & & \\
\hline & High school & 51 & 79.19 & & & \\
\hline & University & 23 & 91.17 & & & \\
\hline & Graduate degree & 3 & 114.67 & & & \\
\hline \multirow{5}{*}{ Self-confidence } & $\begin{array}{l}\text { Illiterate } \\
\text { Literate }\end{array}$ & $\frac{3}{5}$ & $\begin{array}{l}80.83 \\
81.30\end{array}$ & \multirow{5}{*}{5.512} & \multirow{5}{*}{5} & \multirow{5}{*}{.357} \\
\hline & $\begin{array}{l}\text { Primary-secondary } \\
\text { school }\end{array}$ & 86 & 78.05 & & & \\
\hline & High school & 51 & 92.78 & & & \\
\hline & University & 23 & 100.41 & & & \\
\hline & Graduate degree & 3 & 101.17 & & & \\
\hline \multirow{6}{*}{ Truth-seeking } & Illiterate & 3 & 88.33 & \multirow{6}{*}{5.520} & \multirow{6}{*}{5} & \multirow{6}{*}{.356} \\
\hline & Literate & 5 & 106.20 & & & \\
\hline & $\begin{array}{l}\text { Primary-secondary } \\
\text { school }\end{array}$ & 86 & 89.39 & & & \\
\hline & High school & 51 & 85.75 & & & \\
\hline & University & 23 & 75.96 & & & \\
\hline & Graduate degree & 3 & 34.00 & & & \\
\hline \multirow{6}{*}{ Systematicity } & Illiterate & 3 & 77.67 & \multirow{6}{*}{5.511} & \multirow{6}{*}{5} & \multirow{6}{*}{.357} \\
\hline & Literate & 5 & 117.30 & & & \\
\hline & $\begin{array}{l}\text { Primary-secondary } \\
\text { school }\end{array}$ & 86 & 82.99 & & & \\
\hline & High school & 51 & 89.98 & & & \\
\hline & University & 23 & 88.78 & & & \\
\hline & Graduate degree & 3 & 39.33 & & & \\
\hline
\end{tabular}

According to the results of the Kruskal Wallis $\mathrm{H}$ test, no statistically significant difference was found between students' critical thinking tendency according to their mothers' level of education $(p>.05)$. When the Table 9 is examined, it is found that in the "Analyticity" subscale, students whose mothers are "Illiterate" (Mean rank=111.33) have the highest mean critical thinking tendency score while those whose mothers are "High school" graduate (Mean rank=78.29) have the lowest mean score. In the "Open-mindedness" subscale, students whose mothers are "Literate" (Mean rank=119.10) have the highest mean critical thinking tendency score while those whose mothers have "Graduate" degrees (Mean rank=25.50) have the lowest mean score. In the "Inquisitiveness" subscale, students whose mothers are "Literate" (Mean rank=125.70) have the highest mean critical thinking tendency score while those 
Hare KILIÇASLAN. The levels of critical thinking tendencies in architectural education

PROBLEMS

OF EDUCATION

IN THE $21^{\text {st }}$ CENTURY Vol. 76, No. 5, 2018

644

whose mothers are "High school" graduate (Mean rank=79.19) have the lowest mean score. In the "Self-confidence" subscale, students whose mothers have "Graduate" degrees (Mean rank=101.17) have the highest mean critical thinking tendency score while those whose mothers are "Primary-Secondary school" graduate (Mean rank=78.05) have the lowest mean score. In the "Truth-Seeking" subscale, students whose mothers are "Literate" (Mean rank=106.20) have the highest mean critical thinking tendency score while those whose mothers have "Graduate" degrees (Mean rank=34.00) have the lowest mean score. In the "Systematicity" subscale, students whose mothers are "Literate" (Mean rank=117.30) have the highest mean critical thinking tendency score while those whose mothers have "Graduate" degrees (Mean rank=39.33) have the lowest mean score.

A Kruskal Wallis $H$ test was run to determine whether there is any significant difference between students' critical thinking tendencies and their fathers' level of education (Table 10).

Table 10. Results of differences between students' scores of subscales according to their fathers' level of education.

\begin{tabular}{|c|c|c|c|c|c|c|}
\hline Subscales & $\begin{array}{l}\text { Father's level of } \\
\text { education }\end{array}$ & $N$ & Mean rank & $\chi^{2}$ & $S D$ & $p$ \\
\hline \multirow{6}{*}{ Analyticity } & Illiterate & 1 & 104.00 & \multirow{6}{*}{3.468} & \multirow{6}{*}{5} & \multirow{6}{*}{.628} \\
\hline & Literate & 1 & 126.00 & & & \\
\hline & $\begin{array}{l}\text { Primary-secondary } \\
\text { school }\end{array}$ & 48 & 85.49 & & & \\
\hline & High school & 55 & 93.47 & & & \\
\hline & University & 59 & 78.36 & & & \\
\hline & Graduate degree & 7 & 86.86 & & & \\
\hline \multirow{6}{*}{ Open-mindedness } & Illiterate & 1 & 32.50 & \multirow{6}{*}{7.809} & \multirow{6}{*}{5} & \multirow{6}{*}{.167} \\
\hline & Literate & 1 & 119.00 & & & \\
\hline & $\begin{array}{l}\text { Primary-secondary } \\
\text { school }\end{array}$ & 48 & 98.96 & & & \\
\hline & High school & 55 & 80.45 & & & \\
\hline & University & 59 & 84.21 & & & \\
\hline & Graduate degree & 7 & 58.79 & & & \\
\hline \multirow{6}{*}{ Inquisitiveness } & Illiterate & 1 & 131.50 & \multirow{6}{*}{4.562} & \multirow{6}{*}{5} & \multirow{6}{*}{.472} \\
\hline & Literate & 1 & 82.00 & & & \\
\hline & $\begin{array}{l}\text { Primary-secondary } \\
\text { school }\end{array}$ & 48 & 90.36 & & & \\
\hline & High school & 55 & 92.43 & & & \\
\hline & University & 59 & 76.07 & & & \\
\hline & Graduate degree & 7 & 83.36 & & & \\
\hline \multirow{6}{*}{ Self-confidence } & Illiterate & 1 & 35.50 & \multirow{6}{*}{2.050} & \multirow{6}{*}{5} & \multirow{6}{*}{.842} \\
\hline & Literate & 1 & 67.50 & & & \\
\hline & $\begin{array}{l}\text { Primary-secondary } \\
\text { school }\end{array}$ & 48 & 81.43 & & & \\
\hline & High school & 55 & 86.71 & & & \\
\hline & University & 59 & 89.29 & & & \\
\hline & Graduate degree & 7 & 93.93 & & & \\
\hline \multirow{6}{*}{ Truth-seeking } & Illiterate & 1 & 117.50 & \multirow{6}{*}{8.631} & \multirow{6}{*}{5} & \multirow{6}{*}{.125} \\
\hline & Literate & 1 & 6.00 & & & \\
\hline & $\begin{array}{l}\text { Primary-secondary } \\
\text { school }\end{array}$ & 48 & 98.89 & & & \\
\hline & High school & 55 & 86.01 & & & \\
\hline & University & 59 & 76.17 & & & \\
\hline & Graduate degree & 7 & 87.36 & & & \\
\hline \multirow{6}{*}{ Systematicity } & Illiterate & 1 & 35.00 & \multirow{6}{*}{1.494} & \multirow{6}{*}{5} & \multirow{6}{*}{.914} \\
\hline & Literate & 1 & 81.00 & & & \\
\hline & $\begin{array}{l}\text { Primary-secondary } \\
\text { school }\end{array}$ & 48 & 88.25 & & & \\
\hline & High school & 55 & 85.46 & & & \\
\hline & University & 59 & 86.81 & & & \\
\hline & Graduate degree & 7 & 75.93 & & & \\
\hline
\end{tabular}


According to the results of the Kruskal Wallis H test, no statistically significant difference was found between students' critical thinking tendency according to their fathers' level of education $(p>.05)$. When the Table 10 is examined, it is found that in the "Analyticity" subscale, students whose fathers are "Literate" (Mean rank=126.00) have the highest mean critical thinking tendency score while those whose fathers are "University" graduate (Mean rank=78.36) have the lowest mean score. In the "Open-mindedness" subscale, students whose fathers are "Literate" (Mean rank=119.00) have the highest mean critical thinking tendency score while those whose fathers are "Illiterate" (Mean rank=32.50) have the lowest mean score. In the "Inquisitiveness" subscale, students whose fathers are "Illiterate" (Mean rank=131.50) have the highest mean critical thinking tendency score while those whose fathers are "University" graduate (Mean rank=76.07) have the lowest mean score. In the "Self-confidence" subscale, students whose fathers have "Graduate" degrees (Mean rank=93.93) have the highest mean critical thinking tendency score while those whose fathers are "Illiterate" (Mean rank=35.50) have the lowest mean score. In the "Truth-Seeking" subscale, students whose fathers are "Illiterate" (Mean rank=117.50) have the highest mean critical thinking tendency score while those whose fathers are "Literate" (Mean rank=6.00) have the lowest mean score. In the "Systematicity" subscale, students whose fathers are "Primary-Secondary school" graduate (Mean rank=88.25) have the highest mean critical thinking tendency score while those whose fathers are "Illiterate" (Mean rank=35.00) have the lowest mean score.

\section{Discussion}

In the first question of the research, students' critical thinking tendency levels were aimed to be determined. As a result of the analyses, it was determined that the critical thinking tendency levels of the architectural students having participated in the research were generally mediocre. While the sub-dimension where the critical thinking tendency was at the highest level was the "Analyticity", "Systematicity" was the sub-dimension where it was the lowest. In the light of these facts, it can be argued that students' tendencies towards being careful against potentially problematic situations, reasoning even in difficult problems and using objective evidence are higher in comparison to other sub-dimensions. On the other hand, it is seen that their tendencies towards organized, planned and careful inquiry are lower in comparison to other sub-dimensions.

In the second question of the research, it was questioned whether the students' critical thinking tendency levels significantly differ according to their class levels. As a result of the analyses run, no statistically significant difference was found between the critical thinking tendency levels of students according to their class levels. Nevertheless, it is seen that the "Analyticity", "Inquisitiveness", "Systematicity" subscales are higher in favor of the first-year students while the "Self-confidence" and "Truth-seeking" subscales are higher in favor of the fourth-year students. This suggests that the architectural education process should be supported each year with an understanding of education that leads students to think critically. When studies in various disciplines are examined, there are research findings showing that level of critical thinking enhances by the class level (Can \& Kaymakç1, 2015; Spelic et.al., 2001) whereas there are other findings showing that critical thinking does not enhance by the class level (Ekinci \& Aybek, 2010; Profetto-McGrath, 2003).

As a result of the data analyses related to the third question of the research, no significant difference was found between students' critical thinking tendency levels according to their GPAs. However, given the test results presented in Table 2, it is seen fourth-year students' GPAs are higher. The fact that fourth-year students' critical thinking tendencies do not differ significantly although their GPAs are higher can be interpreted as, they are not adequately leaned towards critical thinking.

In the scope of the fourth question, it was questioned whether the students' critical thinking tendency levels significantly differ according to their genders, settlement places and education levels of their parents. Analyses run by the gender variable revealed that the

$\mid$\begin{tabular}{l} 
PROBLEMS \\
OF EDUCATION \\
IN THE 21 $1^{\text {st }}$ CENTURY \\
Vol. 76, No. 5, 2018 \\
\hline 645
\end{tabular} 
Hare KILIÇASLAN. The levels of critical thinking tendencies in architectural education

\begin{abstract}
PROBLEMS
OF EDUCATION

IN THE $21^{\text {st }}$ CENTURY Vol. 76, No. 5,2018

646 difference between students' level of "Analyticity" according to their genders was statistically significant. It was found that females have higher level of "Analyticity" than males. It can be claimed that female students have a higher tendency to be tolerant of different opinions and evaluations, to use objective evidence and reasoning even in the face of difficult problems, and to resort to reasoning processes in comparison to males. Scores obtained from the other subdimensions of the scale did not reveal any significant difference according to gender. Similarly, no statistically significant difference was found as a result of the analyses run according to the settlement places where the students spent most of their lives and parents' level of education. These results are in parallel with some studies in the literature. In the studies by Rudd et al. (2000) and Giancarlo \& Facione (2001) a significant difference was found in favor of females in critical thinking. On the other hand, in the studies by Ricketts \& Rudd (2004), Mitrevski \& Zajkov (2012) and Tümkaya et al. (2009), no significant difference was found between critical thinking tendency of university students according to their genders. Besides, there are studies (Zaybak \& Khorshid, 2006; Atay et al., 2009) specifying that there is no significant difference between critical thinking tendencies according to fathers' and mothers' level of education.
\end{abstract}

\section{Conclusions}

In this research, the critical thinking tendency levels of the first and fourth year students who receive education in Architecture Department of Karadeniz Technical University were determined within the framework of grade point averages and presented with supporting demographic data. The findings show that students' critical thinking tendencies are independent of the variables of their parent educational level and settlement places, where they spend most of their lives. It was determined that the critical thinking tendencies of the architecture students who participated in the research were generally at a moderate level and did not differ according to academic achievement. As a result of this situation, it can be said that architectural education students need to be directed towards critical thinking more. For the very reason, critical thinking skill emerges as one of the qualities that should be given to the students during the architectural education process.

The sample of the research is limited to first and fourth year students in the spring semester of 2018. Since the number of samples covering the majority of the population (first-year $N=94$, fourth-year $N=92$ ), sample strongly represents the population. As a result, samples which are used in this research are representative. To make a general evaluation on architectural education should not be limited only with Architecture Department of Karadeniz Technical University, investigations required to measure and evaluate the students' critical thinking tendencies in some other architecture departments of different universities. In this way in universities which have architecture departments, critical thinking tendencies can be surveyed so comparative analysis works can be carried out.

Starting from the first year, it will be appropriate to provide some guidance to ensure that all students attach importance to critical thinking. In addition to learning what critical thinking is, students should also consider developing their ability to ask effective questions, to be orderly in problem solving and to work diligently, patiently and rationally. Therefore, it is important to establish a good communication environment in both theoretical and practical courses. It should be aimed that students acquire critical thinking habits on any architectural concept, book, material, work etc. they encounter, unlike the thinking patterns they are accustomed to. Dorst (2015) draws attention to the fact that a good designer is a powerful and analytical thinker whose mind works in an original and playful manner.

In understanding and realization of architecture, having a free and guiding learning process that will allow students to realize their own potential is gaining importance. It is believed that the utilization of new and original ideas in the field of architecture together with mind exercises by the instructor of the course will help students move beyond what they know. In such a learning environment, the intellectual productivity of the students should be prioritized 
rather than the instructor's ideas being accepted by the students as the only correct ones. The role of the course instructor in enriching the content of the course, preparing the materials to be used and guiding the provision of a democratic atmosphere is crucial. It is thought that the inclusion of courses or workshops to develop critical thinking in architecture undergraduate program will open the way for improving the current situation.

Based on the results of the research, it may be suggested to prepare settings where students can think about concepts and discuss them within a critical framework in theoretical and practical courses within the curriculum. Lessons -depending on their content- can include discussion-evaluation processes with small or large groups that involve the instructor. Experimental studies, which examine the relationship between critical thinking level and academic achievement at different levels of architecture education, can be planned. Systematic application researches can be carried out to develop critical thinking skills and researches can be conducted to determine how effective these are on the students with various measuring tools.

\section{References}

Atay, S., Ekim, E., Gökkaya, S., \& Sağım, E. (2009). The levels of critical thinking of students in school of health. Journal of Hacettepe University Faculty of Nursing, 16 (1), 39-46.

Büyüköztürk, Ş., Çakmak, E. K., Akgün, Ö. E., Karadeniz, Ş., \& Demirel, F. (2018). Bilimsel araştırma yöntemleri [Scientific research methods]. Ankara, Turkey: Pegem Akademi Yayınc1lık.

Can Ş., \& Kaymakçı, G. (2015). Pre-service teachers' critical thinking tendencies. E-Journal of New World Sciences Academy, 10 (2), 66-83.

Demirel, Ö. (2009). Kuramdan uygulamaya eğitimde program geliştirme [Curriculum development from theory to practice]. Ankara, Turkey: Pegem Akademi Yayıncilık.

Dorst, K. (2015). Frame innovation: Creative new thinking by design. Cambridge, Massachusetts: The MIT Press.

Ekinci, Ö., \& Aybek, B. (2010). Analysis of the empathy and the critical thinking disposition of the teacher candidates. Elementary Education Online, 9 (2), 816-827.

Ennis, R. H. (1985). Goals for a critical thinking curriculum. In A. L. Costa (Ed.), Developing minds: A resource book for teaching thinking (pp. 68-71). Alexandria, VA: Association for Supervision and Curriculum Development.

Ennis, R. H. (1996). Critical thinking dispositions: Their nature and assessability. Informal Logic, 18 (2\&3), 165-182.

Facione, P. A., Facione, N. C., \& Giancarlo, C. A. F. (1998). The California Critical Thinking Disposition Inventory (CCTDI): The CCTDI test manual. Millbrae CA: California Academic Press.

Facione, P. A. (2013). Critical thinking: What it is and why it counts. Millbrae CA: The California Academic Press.

Giancarlo, C. A., \& Facione, P. A. (2001). A look across four years at the disposition toward critical thinking among undergraduate students. The Journal of General Education, 50 (1), 29-55.

Glaser, E. M. (1941). An experiment in the development of critical thinking. New York: Teachers College.

Güleç, D. (1997). Bina enerji performans simülasyonunun mimari tasarım stüdyosuna entegrasyonu [Integration of building energy performance assesment into architectural design studio]. Unpublished master thesis. Ankara, Turkey: Gazi University Graduate School Of Natural And Applied Sciences.

Halpern, D. F. (1999). Teaching for critical thinking: Helping college students develop the skills and dispositions of a critical thinker. New Directions for Teaching and Learning, 80, 69-74. doi: https://doi.org/10.1002/tl.8005.

Karasar, N. (2016). Bilimsel araştırma yöntemi [Scientific research method]. Ankara, Turkey: Nobel Akademik Yayıncilık.

Kökdemir, D. (2003). Belirsizlik durumlarında karar verme ve problem çözme [Decision making and problem solving under uncertainty]. Unpublished doctoral dissertation. Ankara, Turkey: Ankara University Graduate School of Social Sciences.

Lipman, M. (2003). Thinking in education. Cambridge, Massachusetts: Cambridge University Press.

Mitrevski, B., \& Zajkov, O. (2012). Physics lab, critical thinking and gender differences. Macedonian Physics Teacher, 48, 13-18.

$\mid$\begin{tabular}{l} 
PROBLEMS \\
OF EDUCATION \\
IN THE 21 $1^{\text {st }}$ CENTURY \\
Vol. 76, No. 5, 2018 \\
\hline 647
\end{tabular} 
Hare KILIÇASLAN. The levels of critical thinking tendencies in architectural education

PROBLEMS
OF EDUCATION
IN THE $21^{\text {st }}$ CENTURY Vol. 76, No. 5, 2018

648

Nosich, G. M. (2012). Learning to think things through: A guide to critical thinking across the curriculum. Boston: Pearson Education.

Profetto-McGrath, J. (2003). The relationship of critical thinking skills and critical thinking dispositions of baccalaureate nursing students. The Journal of Advanced Nursing, 43 (6), 569-577. doi: https:// doi.org/10.1046/j.1365-2648.2003.02755.x

Ricketts, J. C., \& Rudd, R. (2004). Critical thinking skills of FFA leaders. Journal of Southern Agricultural Education Research, 54 (1), 7-20.

Rudd, R., Baker, M., \& Hoover, T. (2000). Undergraduate agriculture student learning styles and critical thinking abilities: Is there a relationship? Journal of Agricultural Education, 41 (3), 2-12.

Ruggiero, V. R. (2012). Beyond feelings: A guide to critical thinking. New York: McGraw-Hill.

Schafersman, S. D. (1991). An introduction to critical thinking. Retrieved from http://www.freeinquiry. com/critical-thinking.html.

Spelic, S. S., Parsons, M., Hercinger, M., Andrews, A., Parks, J., \& Norris, J. (2001) Evaluation of critical thinking outcomes of a BSN program. Holistic Nursing Practice, 15 (3), 27-34.

Tümkaya S., Aybek, B., \& Aldağ, H. (2009). An investigation of university students' critical thinking disposition and perceived problem solving skills. Eurasian Journal of Educational Research, 36, 57-74.

Uysal M., \& Yıldız, A. (2014). Sunuş [Presentation]. In M. Uysal \& A. Yıldız (Eds.), Eleştirel Ĕ̆gitim Yazıları [Critical Education Articles]. Ankara: Siyasal Kitabevi.

Yücel, S., \& Aydınl1, S. (2015). Speculative experiment based on architect's education. Journal of the Institute of Science and Technology of Erciyes University, 31 (1), 17-23.

Zaybak, A., \& Khorshid, L. (2006). The investigation of the level of critical thinking of students in Ege Unıversity School of Nursing. Ege Üniversitesi Hemşirelik Yüksek Okulu Dergisi, 22 (2), 137146.

Received: July 13, 2018

Accepted: September 20, 2018

Hare Kiliçaslan

PhD, Department of Architecture, Faculty of Architecture, Karadeniz Technical University, Trabzon, Turkey.

E-mail: hkkilicaslan@gmail.com

Website: https://www.researchgate.net/profile/Hare_Kilicaslan 